\title{
Erratum to: ACMT Position Statement: Guidance for the Use of Intravenous Lipid Emulsion
}

\author{
American College of Medical Toxicology
}

Received: 3 May 2016 / Accepted: 3 May 2016/Published online: 25 May 2016

(C) American College of Medical Toxicology 2016

Erratum to: J. Med. Toxicol.

DOI 10.1007/s13181-016-0550-z

On page 1, the fourth paragraph should read:

"There are no validated, evidence-based dosing regimens. The American Heart Association described a $1.5 \mathrm{~mL} / \mathrm{kg}$ bolus followed by a $0.25 \mathrm{~mL} / \mathrm{kg} / \mathrm{min}$ infusion, continued for 30 60 minutes to a maximum infusion of $10 \mathrm{~mL} / \mathrm{kg}$ [11]. Lipidrescue.org recommends repeating this initial bolus one to two times for persistent "cardiovascular collapse," raising the infusion rate to $0.5 \mathrm{~mL} / \mathrm{kg} / \mathrm{min}$ for persistent hypotension, and limiting the total dose to $10-12 \mathrm{~mL} / \mathrm{kg}$ over the first 30 minutes [2]. Additional dosing recommendations include a loading dose of $1.5 \mathrm{~mL} / \mathrm{kg}$, followed by $3-5$ minutes of infusion at $0.25 \mathrm{~mL} / \mathrm{kg}$, and then a maintenance infusion of $0.025 \mathrm{~mL} / \mathrm{kg} / \mathrm{min}$ [9]. This lower infusion rate may be sufficient to maintain the positive effects of lipids while avoiding lipid overload."

The dose is correctly stated in the Recommended Guideline section on page 2 .

The online version of the original article can be found at http://dx.doi.org/ 10.1007/s13181-016-0550-z.

\footnotetext{
American College of Medical Toxicology

positionstatements@acmt.net

1 ACMT, Phoenix, AZ, USA
} 